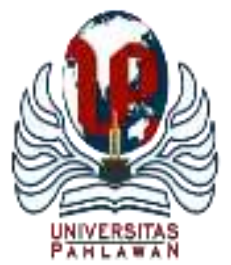

Edukatif : Jurnal Ilmu Pendidikan Volume 3 Nomor 6 Tahun 2021 Halm 4075 - 4082

EDUKATIF: JURNAL ILMU PENDIDIKAN

Research \& Learning in Education

https://edukatif.org/index.php/edukatif/index

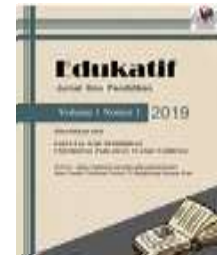

\title{
Pengaruh Model Pembelajaran Example Non Example terhadap Hasil Belajar Siswa pada Pembelajaran Tematik di Sekolah Dasar
}

\author{
Suci Br Sembiring ${ }^{\circledR}$, Darinda Sofia Tanjung ${ }^{2}$, Juliana ${ }^{3}$ \\ Universitas Katolik Santo Thomas, Indonesia ${ }^{1,2,3}$ \\ E-mail : $\underline{\text { ssuci2092@ gmail.com }}{ }^{1}, \underline{\text { darinda tanjung@ } \text { ust.ac.id }^{2}}, \underline{\text { anna.jait@ gmail.com }}^{3}$
}

\begin{abstract}
Abstrak
Penelitian ini bertujuan untuk mengetahui bagaimana pengaruh model pembelajaran example non example terhadap hasil belajar siswa di kelas III SD Negeri 106144 Sei Mencirim tahun pembelajaran 2020/2021. Jenis penelitian ini adalah kuantitatif dengan mengunakan metode one group pretest-posttest design. Populasi penelitian ini seluruh siswa kelas III SD Negeri 106144 Sei Mencirim yang terdiri dari 1 kelas yang berjumlah 30 siswa. Pengambilan sample dengan mengunakan sampling jenuh dan di peroleh sampel sebanyak 30 siswa. Hasil penelitian ini menunjukkan bahwa bahwa hasil belajar siswa dengan mengunakan model example non example termasuk kategori baik dengan rata-rata 84,27. Hasil penelitian ini menunjukkan bahwa hasil pengujian korelasi dapat dilihat pada nilai koefisien korelasi sebesar 0,742 artinya $r_{\text {hitung }}(0,742) \geq r_{\text {tabel }}(0,361)$ maka $\mathrm{H}_{\mathrm{a}}$ diterima. Maka terdapat pengaruh yang kuat antara model pembelajaran example non example terhadap hasil belajar siswa di kelas III SD Negeri 106144 Sei Mencirim. Dapat juga dilihat dari hasil pengujian uji-t dimana $\mathrm{t}_{\text {hitung }} \geq \mathrm{t}_{\text {tabel }}$ yaitu $5,858 \geq 1.701$ sehingga menyatakan bahwa $\mathrm{H}_{\mathrm{a}}$ diterima. Hal ini menunjukkan adanya pengaruh positif yang signifikan dari pengunaan model pembelajaran example non example terhadap hasil belajar siswa di kelas III SD Negeri 106144 Sei Mencirim 106144 tahun pembelajaran 2020/2021.
\end{abstract}

Kata kunci: Hasil Belajar, Model Pembelajaran example non example

\section{Abstract}

This study aims to determine how the influence of the example non-example learning model on student learning outcomes in grade III SD Negeri 106144 Sei Mencirim the 2020/2021 academic year. This type of research is quantitative using the one-group pretest-posttest design method. The population of this study was all third-grade students of SD Negeri 106144 Sei Mencirim which consisted of 1 class of 30 students. Sampling using saturated sampling and obtained a sample of 30 students. The results of this study indicate that student learning outcomes using the example non-example model are in the good category with an average of 84.27. The results of this study indicate that the results of the correlation test can be seen in the correlation coefficient value of 0.742 , meaning that $r_{\text {count }}(0.742) r_{\text {table }}(0.361)$ then Ha is accepted. So there is a strong influence between the example non-example learning model on student learning outcomes in class III $S D$ Negeri 106144 Sei Mencharim. It can also be seen from the results of the t-test where $t_{\text {count }} t_{\text {table }}$ is 5.858 1.701, thus stating that Ha is accepted. This shows that there is a significant positive effect from the use of the example non-example learning model on student learning outcomes in class III SD Negeri 106144 Sei Menistrim 106144 for the 2020/2021 academic year.

Keywords: Learning Outcomes, Learning Model example non example

Copyright (c) 2021 Suci Br Sembiring, Darinda Sofia Tanjung, Juliana

$\triangle$ Corresponding author:

Email : ssuci2092@gmail.com

DOI : https://doi.org/10.31004/edukatif.v3i6.1399 
4076 Pengaruh Model Pembelajaran Example Non Example terhadap Hasil Belajar Siswa pada Pembelajaran Tematik di Sekolah Dasar - Suci Br Sembiring, Darinda Sofia Tanjung, Juliana

DOI: https://doi.org/10.31004/edukatif.v3i6.1399

\section{PENDAHULUAN}

Pendidikan merupakan salah satu usaha manusia untuk lebih meningkatkan dan mengembangkan kepribadian untuk membina potensi dalam diri siswa. Dengan adanya pendidikan akan menjadikan pengetahuan siswa menjadi lebih meluas, serta keterampilan siswa dalam masyarakat akan meningkat sama halnya dengan pengalaman belajar siswa akan lebih bertambah.

Berdasarkan hasil observasi yang telah dilakukan oleh peneliti di SD Negeri 106144 Sei Mencirim peneliti memperoleh informasi bahwa guru masih mengunakan model lama, dengan metode ceramah, tanya jawab, penugasan. Maka proses kegiatan belajar mengajar hanya pusat pada guru. Sehingga siswa kurang aktif dalam belajar. Pada saat guru menjelaskan materi pembelajaran, guru akan menjelaskan materi pembelajaran, guru akan menjelaskan hal yang penting di papan tulis, setelah itu siswa akan menulis ulang pada buku mereka apa yang di catat di papan tulis tersebut. Dan pada saat ujian lebih banyak siswa yang mendapat nilai dibawah KKM dari pada siswa yang mendapatkan di atas KKM. Hal ini disebabkan oleh siswa yang balum paham akan materi yang dijelaskan oleh guru pada saat kegiatan belajar mengajar berlangsung.

Untuk memperbaiki hasil belajar siswa harus memotivasi siswa untuk lebih aktif dalam proses pembelajaran agar mendapatkan hasil belajar yang baik. Ada banyak model pembelajaran yang dapat digunakan dalam proses pembelajaran, akan tetapi peneliti mengunakan model pembelajaran example non example untuk meningkatkan hasil belajar siswa dan lebih meningkatkan siswa untuk lebih aktif.

Menurut Istani (2015 :9) "Model pembelajaran Example Non Example yaitu suatu rangkaian menyampaikan materi ajar kepada siswa dengan menunjukkan gambar gambar yang relavan yang telah di persiapkan dan diberikan kesempatan kepada siswa untuk menganalisisnya bersama temen dalam kelompok yang kemudian diminta hasil diskusi yang dilakukannya" "Model pembelajaran example non example berangkat dari data dokumentasi yang kemudian dikembangkan menjadi suatu kajian materi ajar yang menarik untuk dikaji dan diteliti sehingga di peroleh suatu pengetahuan yang sangat berguna yang sebelumnya tidak diketahui.

Menurut Ngalimun (2017: 244) “ Examples non examples adalah suatu model dalam bentuk persiapan gambar, diagram, atau tabel sesuai materi bahan ajar dan kopetensi, sajikan gambar di tempel atau pakai OHP, dengan petunjuk guru siswa mencermati sajian, diskusi kelompok tentang sajian gambar tadi, persentasi hasil kelompok, bimbingan, penyimpulan, evaluasi dan refleksi”. Example non example merupakan model pembelajaran berupa contoh-contoh gambar untuk mencapai tujuan belajar, melalui proses pembelajaran yang di lakukan siswa dengan guru di kelas tersebut.

Menurut Slameto (2019: 11) "Perkembangan proses belajar pada anak-anak bahwa Piaget berpendapat mengenai teori belajar yaitu : 1) anak mempunyai struktur mental yang berbeda dengan orang dewasa. Mereka bikan merupakan orang dewasa bentuk kecil, mereka punya cara yang khas untuk menyatakan kenyataan dan untuk menghayati dunia sekitarnya, 2) perkembangan mental pada anak melalui tahap-tahap tertentu, menurut suatu urutan yang sama bagi semua anak 3), walaupun berlangsungnya tahap-tahap perkembangan itu melalui suatu urutan tertentu, tetapi jangka waktu untukberlatih dari satu tahap ke tahap yang lain tidak lah selalu sama pada setiap anak, 4) Perkembangan metal anak dipengaruhi oleh faktor kecemasan, pengalaman, interaksi sosial, 5) tahap perkembangan, berfikir secara intuitif, beroprasi secara konkret, beroprasi secara formal.

Dalam suatu perubahan perilaku siswa yang secara relatife berfikir yang di dapat dari sebuah pengelaman dari belajar, latihan, dan pengembangan dari dalam diri. Menurut Komara (2014: 15), "Mengatakan ciri khas belajar adalah perubahan, yaitu belajar menghasilkan perubahan perilaku dalam diri peserta didik. Belajar menghasilkan perubahan perilaku yang secara relative tetap dalam berpikir, merasa dan melakukan pada diri peserta didik". Perubahan tersebut terjadi sebagai hasil latihan, pengalaman, dan 
4077 Pengaruh Model Pembelajaran Example Non Example terhadap Hasil Belajar Siswa pada Pembelajaran Tematik di Sekolah Dasar - Suci Br Sembiring, Darinda Sofia Tanjung, Juliana DOI: https://doi.org/10.31004/edukatif.v3i6.1399

pengembangan yang hasilnya tidak dapat diamati, kalau ia tidak memiliki perubahan berarti dia tidak belajar, kalau ia memiliki perubahan berarti dia belajar, untuk mendapatkan suatu perubahan.

Dalam perubahan tingkah laku sebagai hasil belajar dalam meningkatkan pengetahuan dalam belajar, sikap, dan keterampilan dengan proses belajar mengajar maka akan terjadi perubahan peningkatan hasil belajar Menurut Mappeasse (2018: 3) "Hasil belajar merupakan kemampuan yang dimiliki baik bersifat pengetahuan (kognitif), sikap (afektif), maupun keterampilan (psikomotorik) yang semuanya ini di peroleh melalui proses belajar mengajar. Kemampuan yang dimiliki anak akan berkembang memalui proses belajar mengajar yang di bimbing oleh guru dalam mencapai suatu hasil belajar.

Dalam perubahan perilaku seseorang yang terjadi setelah mengikuti pelajaran mempengaruhi perubahan tingkah laku seseorang dari hal yang mereka tidak tau apa-apa menjadi mengerti karna adanya aspek kognitif, afektif, dan psikomotorik yang mereka pelajari guna untuk mencapai hasil nyata . Menurut Afandi (2013: 4) "Hasil belajar adalah perubahan tingkah laku pada orang dari tidak tau menjadi tau, dari tidak mengerti menjadi mengerti, dan dari belum mampu ke arah sudah mampu". Seorang yang telah melakukan kegiatan belajar maka terlihat terjadinya perubahan dalam salah satu atau beberapa aspek atau tingkah laku sebagai akibat dari hasil belajar.

Menurut Simorangkir dan Tanjung (2019:302) "Pembelajaran tematik adalah pembelajan terpadu dengan mengunakan tema untuk mengaitkan beberapa mata pelajaran sehingga pembelajaran lebih bermakna. Aktivitas belajar siswa tidak hanya berfokus pada kecerdasan konsep bahasa tetapi juga kecerdasan lainnya.

\section{METODE PENELITIAN}

Penelitian ini dilaksanakan di kelas III SD Negeri 106144 Sei Mencirim pada Tahun Pembelajaran 2020/2021. Penelitian ini menggunakan pendekatan kuantitatif dengan metode one group pretest-posttest design. Populasi dalam penelitian ini adalah siswa kelas III SD Negeri 106144 Sei Mencirim yang berjumlah 30 orang. Penelitian ini menggunakan teknik pengambilan sampel sampling jenuh. Sugiyono (2018: 39) mengatakan bahwa Variabel bebas (independen) merupakan variable yang mempengaruhi atau yang menjadi sebab perubahannya atau timbulnya variable terikat, sedangkan variabel terikat (dependen) adalah variable yang dipengaruhi atau yang menjadi akibat, karena adanya variabel bebas". Variabel bebas sering disebut dengan $\mathrm{X}$ dan variabel terikat adalah Y. Dalam penelitian ini, desain penelitian bertujuan untuk mengetahui pengaruh antara dua variabel atau lebih. Pada penelitian ini terdapat dua variabel yaitu variabel bebas dan variabel terikat.

Teknik pengumpulan data yang digunakan adalah angket, tes, dokumentasi. Sedangkan instrumen penelitian yang digunakan adalah lembar tes dan lembar angket. Teknik analisis data terdiri dari uji instrumen penelitian (uji validitas tes, uji reliabilitas) dengan uji persyaratan data menggunakan uji normalitas. Teknik pengolahan (analisis) data menggunakan uji koefisien korelasi dan uji hipotesis dengan menggunkan uji-t. Untuk pengujian data dan analisis data peneliti menggunakan bantuan program microsoft excel dan program spss versi 22 serta pengujian secara manual.

Setelah hasil uji validitas tes pilihan ganda dengan menggunakan rumus korelasi product moment dari 50 soal pilihan berganda terdapat 25 soal yang dinyatakan valid karena $r_{\text {hitung }}>r_{\text {tabel }}$ dan dapat digunakan dalam tes pilihan ganda yang diberikan pada kelas III pada ujian pre test dan post test. Selanjutnya uji reliabilitas berdasarkan analisis data diperoleh nilai reliabilitas seluruh tes adalah 0,84 . Dengan hasil tersebut dapat dikatakan bahwa soal-soal yang dijadikan instrumen penelitian mempunyai reliabilitas yang sangat tinggi.

\section{HASIL DAN PEMBAHASAN PENELITIAN}

Hasil Pre Test yang telah dilaksanakan menunjukkan bahwa kemampuan hasil belajar siswa dikatakan cukup. 
4078 Pengaruh Model Pembelajaran Example Non Example terhadap Hasil Belajar Siswa pada Pembelajaran Tematik di Sekolah Dasar - Suci Br Sembiring, Darinda Sofia Tanjung, Juliana

DOI: https://doi.org/10.31004/edukatif.v3i6.1399

Tabel 1

Distribusi Frekuensi Nilai Pre Test Kelas III

\begin{tabular}{cccc}
\hline Nilai & Frekuensi & Persentase & Kategori \\
\hline $44-49$ & 1 & $3,33 \%$ & Gagal \\
\hline $50-55$ & 2 & $6,66 \%$ & Gagal \\
\hline $56-61$ & 12 & $40 \%$ & Gagal \\
\hline $62-67$ & 7 & $23,33 \%$ & Cukup \\
\hline $68-73$ & 5 & $16,6 \%$ & baik \\
\hline $74-79$ & 3 & $10 \%$ & baik \\
\hline Jumlah & $\mathbf{3 0}$ & $\mathbf{1 0 0 \%}$ & \\
\hline
\end{tabular}

Berdasarkan data di atas, dapat diketahui nilai pre test siswa yaitu : 1 responden 44-49 sebesar 3,33\%, 2 responden memperoleh skor sekitar 50-55 sebesar 6,66\%, 12 responden 56-61 sebesar 40\%,7 responden 62-67 sebesar 23,33\%, 5 responden $68-73$ sebesar $16,6 \%, 3$ responsen $74-79$ sebesar $10 \%$.

Tabel 2

Distribusi Frekuensi Nilai Post Test Kelas III

\begin{tabular}{cccc}
\hline Nilai & Frekuensi & Persentase & Kategori \\
\hline $68-78$ & 8 & $26,66 \%$ & Cukup \\
\hline $79-89$ & 12 & $40 \%$ & Baik \\
\hline $90-100$ & 10 & $33,33 \%$ & Sangat baik \\
\hline Jumlah & $\mathbf{3 0}$ & $\mathbf{1 0 0 \%}$ & \\
\hline
\end{tabular}

Berdasarkan data di atas dapat diketahui nilai Pre Test siswa yaitu: 8 responden memperoleh skor sekitar 68-78 sebesar 26,66\%, 12 responden memperoleh skor disekitar 79-89 sebesar 40\%, 10 responden memperoleh skor sekitar 90-100 sebesar 33,33\%.

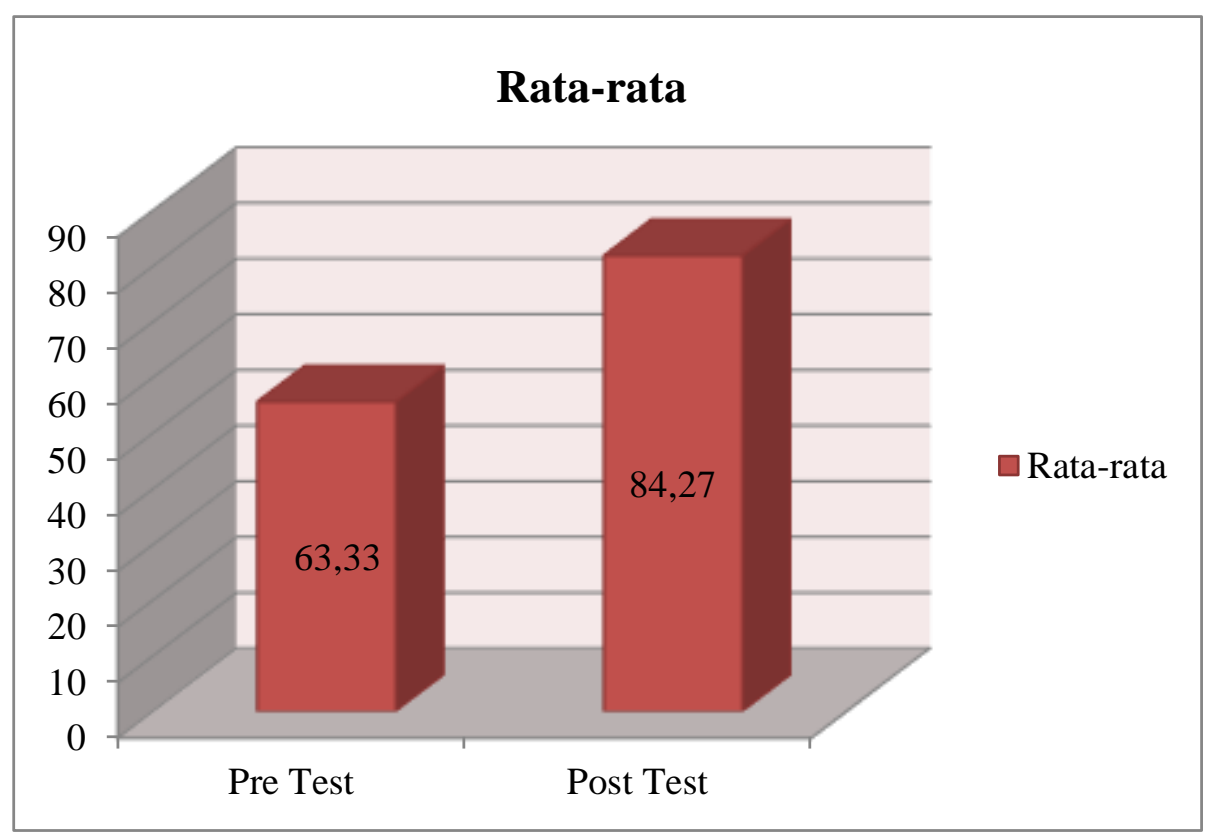

Gambar 1. Diagram Nilai rata-rata Pte Test dan Post Test Kelas III

Hasil pengolahan data angket kelas V B dalam bentuk distribusi frekuensi dilihat di bawah ini:

Tabel 3

Distribusi Frekuensi hasil Angket

\begin{tabular}{ccc}
\hline Nilai & Frekuensi & Presentase \\
\hline $51-52$ & 4 & $13,33 \%$ \\
\hline $53-54$ & 16 & $53,33 \%$ \\
\hline
\end{tabular}

Edukatif : Jurnal Ilmu Pendidikan Vol 3 No 6 Tahun 2021 p-ISSN 2656-8063 e-ISSN 2656-8071 
4079 Pengaruh Model Pembelajaran Example Non Example terhadap Hasil Belajar Siswa pada Pembelajaran Tematik di Sekolah Dasar - Suci Br Sembiring, Darinda Sofia Tanjung, Juliana DOI: https://doi.org/10.31004/edukatif.v3i6.1399

\begin{tabular}{ccc}
\hline $55-56$ & 5 & $16,66 \%$ \\
\hline $57-58$ & 4 & $13,33 \%$ \\
\hline $59-60$ & 1 & $3,33 \%$ \\
\hline Jumlah & $\mathbf{3 0}$ & $\mathbf{1 0 0 \%}$ \\
\hline
\end{tabular}

Berdasarkan data di atas, dapat diketahui nilai angket siswa yaitu: 4 responden memperoleh skor disekitar 51-52 sebesar 13,33\%, 16 responden memperoleh skor disekitar 53-54 sebesar 53,33\%, 5 responden memperoleh skor disekitar 55-56 sebesar 16,66\%, 4 responden memperoleh skor sekitar 13,33\%, 1 responden memperoleh skor disekitar 59-60 sebesar 3,33\%.

Hasil perhitungan normalitas menggunakan SPSS ver 22 terdapat pada tabel 4.8 berikut.

Tabel 4

Normalitas

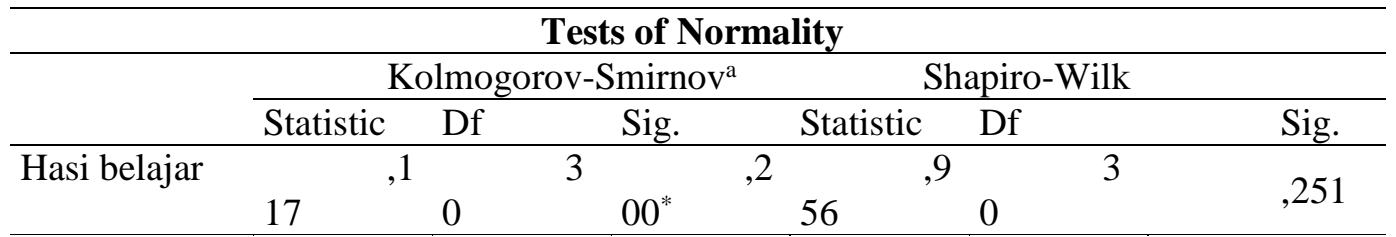

*. This is a lower bound of the true significance.

a. Lilliefors Significance Correction

Nilai taraf signifikasi yang digunakan oleh peneliti adalah taraf signifikasi $5 \%$ atau 0,05 . Berdasarkan SPSS ver 22 didapatkan signifikasi sebesar 200 sehingga disimpulkan sig. 0,200 >0,05 maka data kelas III berdistribusi normal. Selain itu berdasarkan uji liliefors (shapiro-wilk) di dapatkan signifikasi sebesar 0,251 sehingga dapat disimpulkan sig. 0,251>0,05 maka data kelas III dapat dinyatakan berdistribusi normal. Perhitungan normalitas juga dapat melihat kreteria normalitas yaitu jika $\mathrm{L}_{\text {hitung }}<\mathrm{L}_{\text {tabel }}$ dapat dikatakan normal. Maka disimpulkan dengan melihat tabel normalitas maka diproleh nilai signifikasi sebesar $\mathrm{L}_{\text {hitung }} 0,251<\mathrm{L}_{\text {tabel }}$ 0,924.Berdasarkan hasil perhitungan di atas dapat diketahui bahwa data hasil belajar siswa yang berdistribusi normal.

Untuk melihat pengaruh dari kedua variabel dapat dilakukan dengan membandingkan antara $\mathrm{r}_{\text {hitung }}$ dengan $r_{\text {tabel }}$. Dari perhitungan secara manual di atas dapat dilihat nilai koefisien korelasi sebesar 0,742. Sedangkan uji koefisien korelasi berbantuan SPSS ver 22 pada tabel 4.10 dibawah ini:

Tabel 5

Uji Koefisien Korelasi Correlations

\begin{tabular}{|c|c|c|c|}
\hline & & $\begin{array}{l}\text { Model example } \\
\text { non example }\end{array}$ & Hasil belajar \\
\hline \multirow{3}{*}{$\begin{array}{l}\text { Model example } \\
\text { non example }\end{array}$} & Pearson Correlation & 1 &, $742^{* *}$ \\
\hline & Sig. (2-tailed) & & 000 \\
\hline & $\mathrm{N}$ & 30 & 30 \\
\hline \multirow[t]{3}{*}{ Hasil belajar } & $\begin{array}{l}\text { Pearson } \\
\text { Correlation }\end{array}$ &, $742^{* *}$ & 1 \\
\hline & Sig. (2-tailed) & 000 & \\
\hline & $\mathrm{N}$ & 30 & 30 \\
\hline
\end{tabular}

Dari tabel diatas dapat menunjukkan bahwa nilai koefisien korelasi sebesar $0,742 r_{\text {hitung }}(0,742)>r_{\text {tabel }}$ $(0,361)$ maka terdapat pengaruh yang kuat terhadap pengaruh yang kuat antara model pembelajaran example non example terhadap hasil belajar siswa dan terdapat pengaruh antara model pembelajaran example non example terhadap hasil belajar siswa kelas III SD Negeri 106144 Sei Mencirim sebesar 74,2 \%. Dan sebanyak 23,9\% di pengaruhi oleh faktor lain yang tidak dikaji dalam penelitian ini. 
4080 Pengaruh Model Pembelajaran Example Non Example terhadap Hasil Belajar Siswa pada Pembelajaran Tematik di Sekolah Dasar - Suci Br Sembiring, Darinda Sofia Tanjung, Juliana DOI: https://doi.org/10.31004/edukatif.v3i6.1399

Statistic yang digunakan untuk menguji hipotesis penelitian adalah uji t, hipotesis yang di ajukan adalah:

Ha : terdapat pengaruh model pembelajaran example non example terhadap hasil belajar siswa

Ho : tidak terdapat pengaruh model pembelajaran example non example terhapat hasil belajar siswa.

\section{Tabel 6}

Uji-t

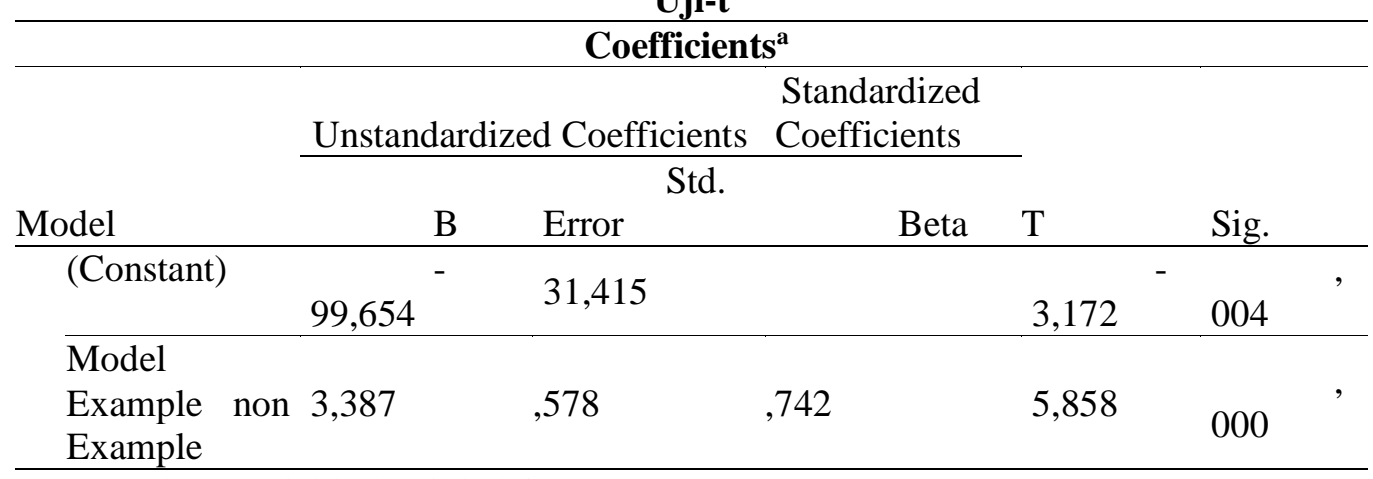

a. Dependent Variable: hasil belajar

Untuk mengetahui ada atau tidaknya pengaruh dapat dilihat hasil signifikat yang di peroleh $0,000<$ 0,05 . Hasil perhitungan uji t dari SPSS ver 22 sebesar 5,858. Untuk mendukung hasil uji t SPSS ver 22, maka berikut hasil uji t secara manual. Dapat diketahui dari nilai $t_{\text {hitung }}>r_{\text {tabel }} 5,858>1,701$ yang artinya ada pengaruh model pembelajaran example non example terhadap hasil belajar siswa.

\section{KESIMPULAN}

Berdasarkan pembahasan bab ini peneliti menguraikan simpulan, implikasi, keterbatasan penelitian dan saranyang disusun berdasarkan kegiatan penelitian mengenai pengaruh model pembelajaran example non example terhadap hasil belajar siswa kelas III SD Negri 106144 Sei Mencirim Tahun Pembelajaran 202012021 sebagai berikut:

Pada kelas III dengan mengunakan model pembelajaran example non example pada materi tema praja muda karana subtema aku suka petualang pembelajaran pembelajaran 2 di SD Negeri 106144 Sei Mencirim Tahun Pembelajaran 2020/2021 kelas III adalah nilai rata-rata Post Test 83,27 berada dengan kategori baik sekali.

Pada kelas III dengan mengunakan model pembelajaran pada materi tema praja muda karana subtema aku suka petualang pembelajaran pembelajaran 2 di SD Negeri 106144 Sei Mencirim Tahun Pembelajaran 2020/2021 kelas III adalah nilai rata-rata Pre Test 63,33 berada dengan kategori kurang baik.

Pada kelas III dengan mengunakan model pembelajaran example non example materi tema praja muda karana subtema aku suka petualang pembelajaran pembelajaran 2 di SD Negeri 106144 Sei Mencirim Tahun Pembelajaran 2020/2021 kelas III hasil angket siswa rata-rata angket tes 54 dengan kategori sangat tinggi

Berdasarkan hasil normalitas dengan mengunakan SPSS ver 22 dengan hasil 0,251 <0,924 yang dapat dikatakan data berdistribusi normal. Berdasarkan pengujian koefisien korelasi dapat dilihat bahwa nilai koefisien korelasi sebesar 0,742 artinya $r_{\text {hitung }}(0,742)>r_{\text {tabel }}(0,361)$.Maka terdapat pengaruh yang kuat dan terdapat pengaruh model pembelajaran example non example terhadap hasil belajar di kelas III SD Negeri 106144 Sei Mencirim. Dan berdasarkan perhitungan hasil peneliti menunjukkan bahwa terdapat pengaruh model pembelajaran example non example terhadap hasil belajar siswa pada tema praja muda karana di kelas III SD Negeri 106144 Sei Mencirim Tahun Pembelajaran 2020/2021 dengan $t_{\text {hitung }}>t_{\text {tabel }}$ dimana 5,858 > 1.701 pada taraf signifikan $\alpha=0,05$. Siswa dengan tema praja muda karana subtema aku suka petualang. Dengan demikian $\mathrm{H}_{\mathrm{a}}$ diterima dan $\mathrm{H}_{\mathrm{o}}$ di tolak. 
4081 Pengaruh Model Pembelajaran Example Non Example terhadap Hasil Belajar Siswa pada Pembelajaran Tematik di Sekolah Dasar - Suci Br Sembiring, Darinda Sofia Tanjung, Juliana DOI: https://doi.org/10.31004/edukatif.v3i6.1399

Penelitian yang dilakukan oleh peneliti dengan menerapkan model pembelajaran example non example juga dapat meningkatkan hasil belajar siswa tema praja muda karana subtema 1 aku suka petualang di kelas III SD Negeri 106144 Sei Mencirim Tahun Pembelajaran 2020/2021.

\section{UCAPAN TERIMA KASIH}

Peneliti mengucapkan puji syukur kepada Tuhan Yang Maha Esa karena atas kasih setia-Nya yang berlimpah penulis dapat menyelesaikan artikel ini dengan baik. Penulis juga tidak lupa mengucapkan terima kasih kepada dosen pembimbing serta semua orang yang terlibat dalam penulisan artikel ini.

\section{DAFTAR PUSTAKA}

Afandi. (2013). Model dan Metode Pembelajaran di Sekolah.

Arikunto, 2017. Dasar-Dasar Evaluasi Pendidikan. Bandung: Pt Bumi Aksara.

Girsang, P. D., Tanjung, D. S., \& Azelina, D. (2021). The Effect of Group Investigation Type Cooperative Learning Model on Students' Learning Outcomes on The Themes of Daerah Tempat Tinggalku at Grade IV SDN 094117 Bangun Saribu. 5(20), 252-261.

Istarani. (2019). 58 Model Pembelajaran Inovatif. Media persada.

Karo, T. B., Anzelina, D., Sembiring, N., \& Tanjung, D. S. (2021). Meningkatkan Hasil Belajar Siswa dengan Menggunakan Model Spider Webbed pada Pembelajaran Tematik. EDUKATIF : JURNAL ILMU PENDIDIKAN, 3(4), 2108-2117.

Mappeasse. (2009). Pengaruh cara dan motivasi belajar terhadap hasil belajar programable logic controller siswa kelas III jurusan listrik smk negri 5 makasar. 1, 3.

Marta, F., Simorangkir, A., \& Tanjung, D. S. (2019). Pendekatan Multiple Intelligences Berbasis Budaya. 7(4), 302-304.

Nainggolan, M., Tanjung, D. S., \& Simarmata, E. J. (2021). Pengaruh Model Pembelajaran S AVI terhadap Hasil Belajar Matematika Siswa di Sekolah Dasar. Jurnal Basicedu, 5(4), 2617-2625.

Ngalimun. (2017). Strategi dan Model Pembelajaran (Ngalimun (ed.)).

Pardosi, B., Tanjung, D. S., \& Anzelina, D. (2020). Pengaruh Model SAVI terhadap Hasil Belajar pada Tema Organ Gerak Hewan dan Manusia di Kelas V SD Negeri 173593 Parsoburan. ESJ (Elementary School Journal), 10(3), 175-184.

Prasetyo, W. E., Kristin, F., \& Anugraheni, I. (2019). Penerapan Model Pembelajaran Cooperative Learning Tipe Group Investigation Untuk Meningkatkan Kerjasama Dan Hasil Belajar Mapel IPA Siswa Kelas 4. Edukatif: Jurnal Ilmu Pendidikan, 1(2), 64-71.

Purba, F. B., Tanjung, D. S., \& Gaol, R. L. (2021). The Effect Of Paikem Approach On Students' Learning Outcomes on The Theme of Lingkungan Sahabat Kita At Grade V SD Harapan Baru Medan Academic Year 2019/2020. Jurnal PAJAR (Pendidikan Dan Pengajaran), 5(2), 278-286.

Purba, J. M., Sinaga, R., \& Tanjung, D. S. (2020). Pengaruh Model Pembelajaran Tipe Kooperatif Tipe Scramble terhadap Hasil Belajar Siswa pada Tema Daerah Tempat Tinggalku Kelas IV. ESJ (Elementary School Journal), 10(4), 216-224.

Saragih, L. M., Tanjung, D. S., \& Anzelina, D. (2021). Pengaruh Model Pembelajaran Open Ended t erhadap Hasil Belajar Siswa pada Pembelajaran Tem atik. Jurnal Basicedu, 5(4), 2644-2652.

Simorangkir, F. M. A., \& Tanjung, D. S. (2019a). Analisis Pelaksanaan Pembelajaran Tematik dengan Pendekatan Multiple Intelligencesberbasis Budaya Batak Angkola untuk Siswa Kelas IV Sekolah Dasar. Jurnal Education and Development, 7(4), 302-304.

Simorangkir, F. M. A., \& Tanjung, D. S. (2019b). Implementation of Multiple Intelligences Approach Based 
4082 Pengaruh Model Pembelajaran Example Non Example terhadap Hasil Belajar Siswa pada Pembelajaran Tematik di Sekolah Dasar - Suci Br Sembiring, Darinda Sofia Tanjung, Juliana DOI: https://doi.org/10.31004/edukatif.v3i6.1399

On Batak Angkola Culture in Learning Thematic For Class IV SD Negeri 100620 Pargarutan Julu South Tapanuli District. Budapest International Research and Critics in Linguistics and Education (BirLE) Journal, 2(4), 547-551. https://doi.org/10.33258/birle.v2i4.538

Sinaga, R., \& Tanjung, D. S. (2019). Efektifitas Penggunaan Interactive Educational Multimedia Learning Berbasis Teori Kognitif terhadap Dyslexic Student di Sekolah Dasar. Jurnal Guru Kita, 3(4), 338-341.

Slameto. (2019). Belajar dan Faktor-faktor yang mempengaruhi. RINEKA CIPTA.

Sugiyono. (2018). Metode Penelitian Pendidikan. Alfabeta.

Tanjung. 2016. Meningkatkan Hasil Belajar Ips Siswa Dengan Menerapkan Model Pembelajaran Kooperatif Tipe Team Games Tournament (TGT) di Kelas V SDN 200111 Padangsidimpuan. Juril AMIK MBP, IV(1), 73.

Tarigan, E. B., Simarmata, E. J., Abi, A. R., \& Tanjung, D. S. (2021). Peningkatan Hasil Belajar Siswa dengan Menggunakan Model Problem Based Learning pada Pembelajaran Tematik. EDUKATIF : JURNAL ILMU PENDIDIKAN, 3(4), 2294-2304.

Yensy. 2012. Penerapan Model Pembelajaran Kooperatif Tipe Example Non Example Dengan Mengunakan Alat Peraga Untuk Meningkatkan Hasil Belajar Siswa Di Kelas VIII Di SMP Negri 1 Agamakmur, p. 25. 